\title{
Tsafon
}

Revue d'études juives du Nord

73 | 2017

Connaissance de la Shoah : témoignages, enseignements, visites

\section{Carol Iancu, Alexandre Safran et les Juifs de Roumanie durant l'instauration du communisme. Documents inédits des archives diplomatiques américaines et britanniques, 1944-1948}

Danielle Delmaire

\section{OpenEdition}

\section{Journals}

Édition électronique

URL : https://journals.openedition.org/tsafon/337

DOI : $10.4000 /$ tsafon.337

ISSN : 2609-6420

Éditeur

Association Jean-Marie Delmaire

Édition imprimée

Date de publication : 1 juin 2017

Pagination : 189-190

ISSN : 1149-6630

Référence électronique

Danielle Delmaire, «Carol lancu, Alexandre Safran et les Juifs de Roumanie durant l'instauration du communisme. Documents inédits des archives diplomatiques américaines et britanniques, 1944-1948 », Tsafon [En ligne], 73 | 2017, mis en ligne le 31 mai 2018, consulté le 01 juillet 2021. URL : http:// journals.openedition.org/tsafon/337 ; DOI : https://doi.org/10.4000/tsafon.337

Ce document a été généré automatiquement le 1 juillet 2021.

Tsafon. Revues d'études juives du Nord 


\title{
Carol Iancu, Alexandre Safran et les Juifs de Roumanie durant l'instauration du communisme. Documents inédits des archives diplomatiques américaines et britanniques, 1944-1948
}

\author{
Danielle Delmaire
}

\section{RÉFÉRENCE}

Carol Iancu, Alexandre Safran et les Juifs de Roumanie durant l'instauration du communisme. Documents inédits des archives diplomatiques américaines et britanniques, 1944-1948, Iasi (Roumanie), édition de l'université Alexandru Ioan Cuza, 2016, 561 pages.

1 Le calvaire des Juifs de Roumanie ne prit pas fin avec la défaite des nazis. Le retour des déportés, dans les camps ou en Transnistrie, se fit très lentement, la réappropriation des biens se fit attendre et l'antisémitisme ne disparut, tout à coup, à la Libération.

D'abord, les responsables de la persécution restèrent en place, ensuite la montée et l'instauration du communisme prit la relève des fascistes. L'État n'eut de cesse, entre 1944 et 1948, de mettre au pas toutes les strates de la société, à commencer par les adeptes de diverses religions et les Juifs plus spécialement. Le parti des paysans fut également particulièrement visé. Le dévouement du grand rabbin Alexandre Safran, déjà bien efficace durant la guerre, continua à se déployer sans cesse, dans ce contexte de prise du pouvoir par les communistes, jusqu'à son expulsion brutale, hors de Roumanie, en décembre 1947. Il fut efficacement aidé et soutenu par le Dr Filderman.

Ce sont les preuves de cette persécution que le professeur émérite Carol Iancu, de l'université de Montpellier 3, met en évidence dans ce recueil de nombreux documents 
inédits, dormant jusqu'à cette publication dans différents fonds d'archives et désormais à disposition des historiens de la Roumanie et/ou du communisme.

4 Une première partie, en une longue introduction d'une centaine de pages, rappelle l'histoire de la difficile période de l'après guerre pour les Roumains (les turbulences politiques engendrent une situation économique désastreuse et une famine mortelle) et pour les Juifs du pays. L'auteur montre dans ces pages tout son talent d'historien très bien documenté et spécialiste de la Roumanie dont il est originaire.

5 Une seconde partie rassemble, en une cinquantaine de pages, les tables chronologiques et analytiques de chaque document. En réalité, dans ces pages, chaque document est résumé. Cette partie se présente donc comme un corpus fort utile qui permet au lecteur de trier rapidement parmi les documents, présentés en troisième partie, ceux qui l'intéressent davantage. Le lecteur peut remercier l'auteur d'avoir eu cette bonne idée de l'aider dans sa recherche.

6 L'édition de 120 documents d'archives et 90 articles de 22 journaux de 7 pays occupe environ les 270 pages des troisième et quatrième parties. Ce sont des documents bruts qui sont livrés, précédés d'une rapide introduction.

7 Les cinquième et sixième parties reproduisent les fac-similés de divers documents : télégrammes, lettres et notes diplomatiques, rapports de diverses missions envoyées en Roumanie par quelques pays, et d'articles de presse anglaise, roumaine, américaine, palestinienne.

8 Enfin suivent des reproductions de photos du grand rabbin et de sa famille (une vingtaine de photos sur une quinzaine de pages). Un index des noms de personnes et un index géographique closent ce volumineux ouvrage.

9 Par le nombre de documents mis à leur disposition, par leur présentation développée et par l'apparat critique qui les accompagne, les chercheurs ont désormais à leur disposition un excellent instrument de travail pour mieux faire connaître l'histoire des lendemains de la Seconde guerre mondiale en Roumanie et pour s'intéresser à l'histoire des Juifs au lendemain de la chute des nazis. 